\title{
Banks, government Bonds, and Default: What do the data Say?
}

\author{
Nicola Gennaioli ${ }^{\mathrm{a}}$, Alberto Martin ${ }^{\mathrm{b}, *}$, Stefano Rossi ${ }^{\mathrm{a}}$ \\ a Università Bocconi, Via Roentgen 1, Milano, 20136, Italy \\ ${ }^{\mathrm{b}}$ CREI, UPF AND Barcelona GSE, Ramon Trias Fargas 25-27, Barcelona, 08005 Spain
}

\section{A R T I C L E I N F O}

\section{Article history:}

Received 30 June 2015

Revised 18 April 2018

Accepted 18 April 2018

Available online 20 April 2018

\section{JEL classification:}

F34

F36

G15

H63

Keywords:

Sovereign Risk

Sovereign Default

Government Bonds

\begin{abstract}
A B S T R A C T
This paper analyzes sovereign bondholdings by 20,000 banks in 191 countries and 20 sovereign default episodes over 1998-2012, establishing two robust facts. First, banks hold many government bonds (on average $9 \%$ of assets) in normal times, particularly banks making fewer loans and operating in less financially-developed countries. Second, during default years, banks with the average exposure to government bonds exhibit a lower growth rate of loans than banks without bonds (7-percentage points lower). These results indicate that the "dangerous embrace" between banks and their government plays a key role during sovereign defaults and its strength depends on local conditions.
\end{abstract}

(c) 2018 The Authors. Published by Elsevier B.V. This is an open access article under the CC BY-NC-ND license. (http://creativecommons.org/licenses/by-nc-nd/4.0/)

\section{Introduction}

Recent theory shows that when banks hold large amounts of sovereign bonds, a sovereign default may hurt their balance sheets, causing a decrease in lending, a banking crisis, and a decline in economic activity (e.g., Gennaioli et al., 2014). This mechanism was center stage during the recent European crisis, but there is scant systematic evidence of it. This paper aims to fill this gap by documenting basic facts from many default episodes around the world.

\footnotetext{
मे We are grateful for helpful suggestions from Ricardo Reis (the Editor), several anonymous referees, and from participants at the Columbia conference on Macroeconomic Policy and Safe Assets, the Wharton conference on Liquidity, the Darden International Finance Conference, the NBER Summer Institute Meetings, the Banque de France/Sciences Po/CEPR conference on "The Economics of Sovereign Debt and Default," the ECGI workshop on Sovereign Debt, the Barcelona GSE Summer Forum, the conference on macroeconomic fragility at the University of Chicago Booth School of Business, and from seminar participants at the University of Illinois at Urbana-Champaign, the Norwegian School of Economics, the Stockholm School of Economics, and HKUST. We also thank Andrea Beltratti, Stijn Claessens, Mariassunta Giannetti, Linda Goldberg, Sebnem Kalemli-Ozcan, Colin Mayer, Camelia Minou, Paolo Pasquariello, Hélène Rey, Sergio Schmukler, Philipp Schnabl, and Michael Weber. Jacopo Ponticelli and Xue Wang provided excellent research assistantship. Gennaioli thanks the European Research Council (grant ERC-GA 241114). Martin acknowledges support from the European Research Council (Consolidator Grant FP7-615651-MacroColl), the Spanish Ministry of Science and Innovation (grant Ramon y Cajal RYC-2009-04624), the Spanish Ministry of Economy and Competitivity (grant ECO2011-23192), the Generalitat de Catalunya-AGAUR (grant 2009SGR1157), the Ramón Areces Grant and the IMF Research Fellowship.

* Corresponding author.

E-mail addresses: nicola.gennaioli@unibocconi.it (N. Gennaioli), amartin@crei.cat (A. Martin), stefano.rossi@unibocconi.it (S. Rossi).
} 
Existing bank-level evidence on this phenomenon faces two main limitations. ${ }^{1}$ First, it focuses on the European debt crisis (e.g., Popov and Van Horen, 2014, De Marco, 2017, Battistini et al., 2014), which limits its scope. It would be useful to know how the "dangerous embrace" between banks and governments works around the world, including in poor and emerging economies, which account for the lion's share of default episodes. Second, existing work does not analyze how banks become exposed to their government in the first place. Acharya and Steffen (2014) and Drechsler et al. (2014) stress banks' excessive risk taking in government bonds during the European crisis, but the importance and generality of this channel remains to be assessed.

To address these issues, we analyze how bank holdings of government bonds shape the sovereign default-banking crisis nexus in many countries, time periods, and crises. We use the BANKSCOPE dataset, which has the advantage - relative to the European Stress tests - of reporting the holdings of government bonds (alternatively, "bondholdings" or "bonds" ) and characteristics of over 20,000 banks in 191 countries between 1998 and 2012. Crucially, our dataset covers 20 sovereign default episodes, 19 of which occurred in emerging markets. ${ }^{2}$

Despite its richness, our data do not allow us to identify causal patterns. Our goal is to unveil robust stylized facts on the cross-country patterns of sovereign crises that can inform future theoretical work. Our analysis delves around two questions:

i. Which banks, and in which countries, hold government bonds? Do banks hold bonds all of the time, or do they mostly buy bonds in the run-up to and during sovereign defaults?

ii. Do the banks that hold more government bonds exhibit a larger decrease in lending when their government defaults?

We address these questions by running a large battery of tests. In particular, our regressions control for many aggregate economic shocks, for differential exposure of banks to such shocks, and for a host of bank characteristics. We document two robust facts:

1. There is a negative and statistically significant correlation between a bank's holdings of domestic government bonds during a sovereign default and its ratio of loans to assets. This result holds within the same defaulting country and default year. A bank holding the average amount of bonds reduces its loans-to-assets ratio by about one extra percentage point relative to a bank holding zero bonds. In addition, for a given loans-to-assets ratio, a bank's bondholdings are associated with lower asset growth during default. As a result, during default years, a bank holding the average exposure to government bonds exhibits a 7-percentage point lower growth rate of loans relative to a bank holding no bonds.

2. During normal times, banks' holdings of government bonds are large (around $9 \%$ of assets), particularly for banks that make fewer loans and are located in less financially developed countries. During default episodes, bondholdings go up only slightly and their increase is concentrated in larger (and more profitable) banks. Government bonds held ahead of crises have a strong predictive power for the reduction in bank lending.

Although these findings cannot fully address causality, they do shed light on the two main hypotheses behind the sovereign default-banking crisis nexus. The "demand channel" hypothesis holds that bank lending does not drop due to default per se, but due to contemporaneous adverse shocks (recessions, devaluations, etc.) that reduce the demand for credit. The alternative "supply channel" hypothesis holds instead that defaults directly hinder bank lending by damaging the balance sheets of banks that hold government bonds. ${ }^{3}$

Fact 1 above is already suggestive of the supply channel. In fact, it implies that a bank's bondholdings predicts its decline in lending during defaults conditional on any contemporaneous aggregate shock. If the decline in lending was only caused by these shocks, there would be no particular reason for it to be stronger among banks holding more government bonds.

This evidence is of course not enough to establish a supply channel. It may in fact be the case that banks highly exposed to their government face low credit demand during defaults, for instance because they disproportionately lend to pro-cyclical firms. However, we find that the lending policy of highly exposed banks is not disproportionately sensitive to recessions or devaluations. Hence, differential sensitivity to major shocks is unlikely to account for our results. In addition, our results are robust to controlling for bank characteristics and their interaction with default. Finally, we also document that bonds held well before sovereign defaults strongly predict the post-default decline in credit, which is also consistent with the supply channel. Arguably, pre-crisis bonds are held for reasons that have little to do with the crisis itself.

Together with Fact 2, this last finding also sheds new important light on the origins of the sovereign default-banking crisis nexus. Because banks' sovereign exposure is mostly built well before defaults, the "dangerous embrace" in our data

\footnotetext{
1 Gennaioli et al. (2014) show that countries where banks hold more domestic public bonds exhibit a sharper reduction in aggregate lending during public default. Arteta and Hale (2008) show that defaults are followed by a drop in foreign credit to domestic firms. Borensztein and Panizza (2008) show that defaults are followed by larger GDP contractions when they occur with banking crises. Baskaya and Kalemli-Ozcan (2014) offer evidence from Turkey. Becker and Ivashina (2014) find that public bond purchases by European banks crowd-out lending.

${ }^{2}$ One shortcoming of BANKSCOPE is that it reports a bank's aggregate public bond exposure, without separating domestic from foreign bonds. To assess the severity of this problem, we focus on a subsample of banks where we perfectly observe the nationality of banks' bondholdings and we thoroughly compare it with our BANKSCOPE data. The exercise confirms the presumption of strong home bias in sovereign exposures, indicating that - while imperfect - the BANKSCOPE measure is a good proxy for a bank's exposure to its domestic government.

${ }^{3}$ This channel relies on the assumption of 'imperfect discrimination' (Broner, Martin, and Ventura, 2010; Broner and Ventura, 2011), whereby governments cannot spare domestic creditors when defaulting on foreign ones. Conventional models of sovereign default assume perfect discrimination instead (e.g., Eaton and Gersovitz, 1981).
} 
seems largely due to banks' demand for bonds in normal times. This is not to say that the risk-taking channel, much discussed in the European context, is not a contributing factor. Rather, our data indicate that this is not an essential or even an important part of the story in emerging markets.

The cross-country nature of our data also allows us to document important country-level differences in the unfolding of sovereign crises. We find that the negative association between bank bondholdings and lending tends to be stronger in defaulting countries that have a fixed exchange rate regime, that are more economically developed, and that have stronger political and financial institutions. These findings are obtained by comparing countries with low versus medium scores of institutions and development, because there are very few defaults among countries with highest scores (perhaps precisely because the cost of default is too large there).

The paper proceeds as follows. Section 2 describes the data. Section 3 studies the basic correlation between bank bondholdings and loans during default (Section 3.1) and the demand for public bonds by banks (Section 3.2). Section 4 concludes.

\section{Data}

We construct a dataset that includes banks' holdings of public bonds and lending activity at the bank-year level, as well as a large set of bank-level characteristics and macroeconomic indicators that capture the state of a country's economy.

\subsection{BANKSCOPE accounting data}

All the bank-level accounting data are obtained from the BANKSCOPE dataset, which contains information on the holdings of government bonds for 20,337 banks in 191 countries between 1998 and 2012 (99,328 bank-year observations). This dataset, which is provided by Bureau van Dijk Electronic Publishing (BvD), contains balance sheet information on a broad range of bank characteristics: bondholdings, size, leverage, risk taking, profitability, amount of loans outstanding, balances with the Central Bank, and other interbank balances. The nationality of the bonds is not reported, an issue to which we return below. The information in BANKSCOPE is suitable for international comparisons because BvD harmonizes the data.

All items are reported at book value, including bonds. ${ }^{4}$ Arguably, since they play a key role in bank regulation, bookvalue estimates influence banks' lending decisions. Indeed, in our sample the book value of bonds does appear to matter for lending. One important implication of book-value accounting is that - to a large extent - variations in the bonds-to-assets ratio capture variations in the relative quantity, as opposed to the market price, of bonds held by banks. ${ }^{5}$

Our dataset is constructed by assembling all annual updates of the unconsolidated accounts of banks in BANKSCOPE. We filter out duplicate records, banks with negative values of all types of assets, banks with total assets smaller than $\$ 100,000$, and years prior to 1997 when coverage is less systematic. This procedure yields 99,328 observations of bondholdings at the bank-year level over 1998-2012. We impose two additional requirements on the remaining banks. First, each bank must have at least two consecutive years of data, so that we can examine changes in lending. Second, each bank must have data on the other main variables: leverage, profitability, cash and short-term securities, exposure to the Central Bank, and interbank balances. The constant-continuing sample for our regressions includes 7,391 banks in 160 countries for a total of 36,449 bank-year observations. We take the location of banks to be the one of its headquarters, as reported in BANKSCOPE. Commercial banks account for $33.2 \%$ of our sample; cooperative banks for $38.2 \%$; savings banks for $20.6 \%$; investment banks for $1.6 \%$; the rest includes holdings, real estate banks, and other credit institutions.

\subsection{Bondholdings data}

Because BANKSCOPE does not break down bonds by nationality, we now check whether the BANKSCOPE measure of government bonds is a good enough proxy for domestic bonds. To be sure, home bias - the tendency of investors to prefer domestic securities - is widespread in international financial markets (see Karolyi and Stulz, 2003 for a survey), so it is reasonable to conjecture that there is home bias in banks' sovereign exposures as well. To assess whether this is the case, we compare our data with other sources that report the nationality of bonds: the country-level measure of "banks' net claims on the government" from the IMF, the bank-level data from the European Stress Tests of 2010-2012 for the subsample of EU banks, and proprietary data from the Central Bank of Argentina for the subsample of Argentine banks during 1997-2004.

Fig. 1 plots averages by country-year of bank bondholdings as a share of total bank assets from BANKSCOPE and from the IMF measure of "financial institutions' net claims to the government" also computed as a share of total assets. ${ }^{6}$ The mean of the IMF measure is very close to the BANKSCOPE data throughout the sample. The difference between both measures is

\footnotetext{
${ }^{4}$ Even in developed economies, banks hold a large fraction of their government bonds in the banking book (which reports book values) rather than in their trading book (which is marked to market). Acharya, Drechsler, and Schnabl (2014) report that EU banks hold on average 85\% of their bonds in their banking book.

${ }^{5}$ Book and market value are close to one another during normal times, when bond prices are close to parity. The online appendix shows that our bookvalue measure approximates fairly well banks' exposure to government bonds at market value and that, if anything, it underestimates in many cases the exposure computed at market values.

6 This variable reports commercial banks' holdings of securities plus direct lending minus government deposits. An equivalent measure has been used by Gennaioli, Martin, and Rossi (2014) and by Kumhof and Tanner (2008).
} 


\section{Bank Bondholdings from Bankscope and IMF}

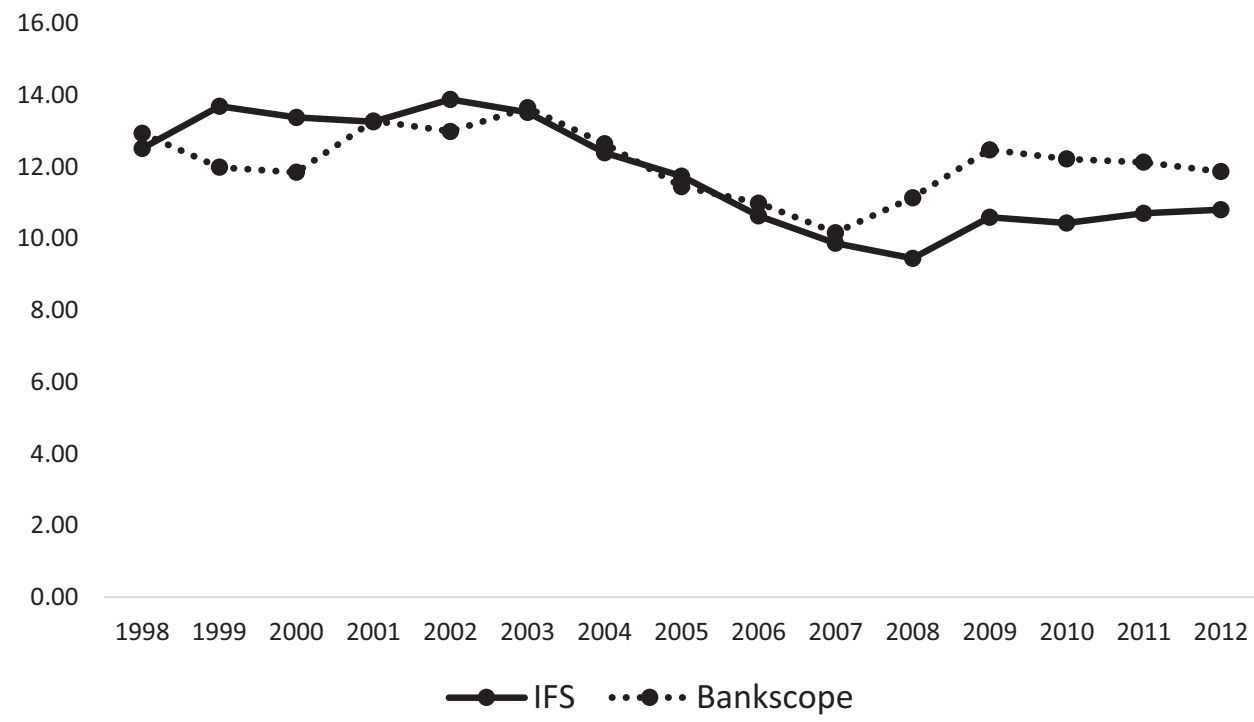

Fig. 1. Bank Bondholdings from BANKSCOPE and IMF. The figure plots bank bondholdings over 1998-2012 for all country-years covered by both BANKSCOPE and the IMF.

Table 1

Bank's holdings of government bonds from BANKSCOPE and other Sources.

\begin{tabular}{|c|c|c|c|c|c|c|}
\hline \multirow{2}{*}{$\begin{array}{l}\text { Sample } \\
\text { Source }\end{array}$} & \multicolumn{2}{|l|}{ EU Banks } & \multicolumn{2}{|l|}{ GIIPS Banks } & \multicolumn{2}{|c|}{ Argentine Banks } \\
\hline & BANKSCOPE & $\overline{\text { Stress Test }}$ & BANKSCOPE & $\overline{\text { Stress Test }}$ & BANKSCOPE & Central Bank \\
\hline Mean & 8.16 & 5.12 & 9.43 & 6.22 & 14.23 & 11.34 \\
\hline Median & 7.68 & 4.44 & 8.22 & 5.64 & 10.73 & 8.09 \\
\hline Correlation & \multicolumn{2}{|c|}{0.69} & \multicolumn{2}{|c|}{0.76} & \multicolumn{2}{|c|}{0.77} \\
\hline \multicolumn{7}{|l|}{ Sample } \\
\hline Period & \multicolumn{2}{|c|}{$2010-2012$} & \multicolumn{2}{|c|}{ 2010-2012 } & \multicolumn{2}{|c|}{ 1997-2004 } \\
\hline No Obs. & \multicolumn{2}{|c|}{126} & \multicolumn{2}{|c|}{65} & \multirow{2}{*}{\multicolumn{2}{|c|}{$\begin{array}{l}589 \\
142\end{array}$}} \\
\hline No Banks & \multicolumn{2}{|c|}{66} & \multicolumn{2}{|c|}{33} & & \\
\hline
\end{tabular}

The table reports summary statistics of bank bondholdings as a percentage of total assets for selected samples.

quite small, less than $0.5 \%$ of assets in more than half of the sample. The BANKSCOPE measure is either equal or slightly larger than the IMF one in most of the years, as can be expected given that it includes also foreign bondholdings. ${ }^{7}$

Country-level IMF data can give us a sense of the reliability of the BANKSCOPE measure of bonds at the country level, but not at the bank level. We therefore consider two alternative sources of bank-level data: the EU stress tests of 2010, 2011, and 2012, and proprietary data from the Argentina's Central Bank during 1997-2004.

Table 1 reports the mean and the median of the bonds-to-assets ratio according to BANKSCOPE and to these alternative data sources. It also reports the bank-level correlations between the ratios reported in these different datasets.

The European stress test data is reassuring. Mean bondholding as a share of assets in the stress test (5.12\%) is fairly close to the BANKSCOPE measure (8.16\%), suggesting that domestic bonds capture the bulk of sovereign exposure. This is also true for GIIPS banks, for which the stress test reports mean bondholdings of $6.22 \%$ against $9.43 \%$ of BANKSCOPE. The bank-by-bank correlation between the BANKSCOPE and stress test measures is sizeable (0.69 overall and 0.76 for GIIPS banks). Consider next the data on Argentine banks. Around the Argentine crisis and default (1997-2004), Argentine banks held $11.34 \%$ of their assets in domestic bonds, while BANKSCOPE reports bondholdings of $14.49 \%$ of assets. ${ }^{8}$ The bank-level correlation is higher than that of the EU Stress Test (0.77), which again confirms the validity of our BANKSCOPE measure. Insofar as noise in the BANKSCOPE measure represents classical measurement error, it should bias our empirical analysis

\footnotetext{
${ }^{7}$ Exceptions are 1999, 2000 and 2002 where the IMF measure overshoots the BANKSCOPE one by $1-1.7 \%$ of assets, which is probably due to the fact that the former includes direct lending.

${ }^{8}$ Importantly, our Argentine data clearly distinguishes between bondholdings held by banks "on their own" and new bond issues, which were used to compensate banks in the aftermath of the 2001 Argentine default. Only the former measure is used in our analysis.
} 
Table 2

Descriptive statistics.

\begin{tabular}{|c|c|c|c|c|c|c|c|c|c|c|}
\hline & \multirow[t]{2}{*}{ Overall } & \multicolumn{2}{|l|}{ All Countries } & \multirow[b]{2}{*}{ Diff. } & \multicolumn{2}{|c|}{ Defaulting Countries } & \multirow[b]{2}{*}{ Diff. } & \multicolumn{2}{|l|}{ Overall } & \multirow[b]{2}{*}{ Diff. } \\
\hline & & Non-Default & Default & & Non-Default Yrs & Default Yrs & & OECD & Non-OECD & \\
\hline Mean & 9.28 & 9.06 & 13.77 & $-4.71^{* * *}$ & 13.51 & 14.49 & $-0.98^{* *}$ & 8.43 & 12.39 & $-3.96^{* * *}$ \\
\hline Median & 5.15 & 5.02 & 9.04 & & 9.02 & 9.15 & & 4.47 & 8.11 & \\
\hline Std Deviation & 11.24 & 11.03 & 14.23 & & 13.79 & 15.35 & & 10.60 & 12.85 & \\
\hline No Banks & 20,337 & 19,714 & 623 & & 571 & 501 & & 16,401 & 3,976 & \\
\hline No Countries & 191 & 157 & 34 & & 34 & 24 & & 34 & 157 & \\
\hline No Bank-Year Obs. & 99,328 & 94,744 & 4,584 & & 3,359 & 1,225 & & 78,118 & 21,210 & \\
\hline
\end{tabular}

Panel B - BANKSCOPE, Constant-continuing sample

\begin{tabular}{|c|c|c|c|c|c|}
\hline & Mean & Median & Std Deviation & No Countries & No Observations \\
\hline Bondholdings & 6.7 & 2.8 & 9.4 & 160 & 36,449 \\
\hline Assets $(\$ / M)$ & $9,922.0$ & 725.6 & $81,400.0$ & 160 & 36,449 \\
\hline Non-cash assets & 95.8 & 97.6 & 5.6 & 160 & 36,449 \\
\hline Leverage & 91.0 & 93.3 & 8.4 & 160 & 36,449 \\
\hline Loans & 57.1 & 60.0 & 17.0 & 160 & 36,449 \\
\hline Profitability & 0.9 & 0.7 & 2.1 & 160 & 36,449 \\
\hline Exposure to Central Bank & 3.3 & 1.5 & 4.9 & 160 & 36,449 \\
\hline Interbank Balances & 12.2 & 9.2 & 12.5 & 160 & 36,449 \\
\hline Government Owned & 2.5 & 0.0 & 15.7 & 160 & 36,449 \\
\hline
\end{tabular}

Panel C - EU banks involved in the EU stress test 2010

\begin{tabular}{lllll}
\hline & Mean & Median & Std Deviation & No Countries \\
\hline Assets $(\$ / M)$ & $394,000.0$ & $130,000.0$ & $618,000.0$ & 18 \\
Non-cash assets & 97.6 & 98.3 & 1.9 & 18 \\
Leverage & 93.3 & 93.8 & 4.2 & 18 \\
Loans & 64.8 & 67.2 & 13.9 & 79 \\
Profitability & -0.1 & 0.3 & 1.9 & 79 \\
Exposure to Central Bank & 1.7 & 1.0 & 1.9 & 79 \\
Interbank Balances & 5.9 & 4.7 & 4.7 & 11 \\
Government Owned & 0.0 & 0.0 & 0.1 & 79 \\
\hline
\end{tabular}

The table reports summary statistics of the main variables. Panel A reports summary statistics of the banks' holdings of government bonds, computed as a percentage of total assets. ${ }^{* *}$ indicates significance at the $1 \%$ level; ${ }^{* *}$ indicates significance at the $5 \%$ level; $*$ indicates significance at the $10 \%$ level. Panel B reports statistics on the BANKSCOPE universe and Panel C on banks involved in the EU stress test of 2010. Assets is the total book value in million $\$$ of the assets side of the bank's balance sheet; non-cash assets is total assets minus cash and due from banks, divided by total assets; leverage is one minus book value of equity (issued share capital plus other shareholders fund) divided by total assets; loans is total loans outstanding divided by total assets; profitability is operating income divided by total assets; exposure to central bank is total exposure to central bank divided by total assets; interbank balances is interest-earning balances with central and other banks divided by total assets; government owned is a dummy that equals one if the government owns more than $50 \%$ of the bank's equity. For details on the construction of all variables see Table A1 in the online appendix.

against finding any results. In the case of Argentina, we can precisely quantify even non-classical measurement error, which also appears to dampen our results, at least in the sub-sample of Argentine banks. ${ }^{9}$

The comparison of the BANKSCOPE data with both IMF country-level data and with the bank-level data of the EU Stress Tests and the Central Bank of Argentina confirms the presumption of a strong home bias in banks' bondholdings, and it also indicates that the BANKSCOPE measure is strongly and significantly correlated with domestic government exposure. As such, we believe the BANKSCOPE measure is a valid proxy for domestic bondholdings and we use it in our analysis.

Panel A of Table 2 reports descriptive statistics on these bondholdings around the world. In non-defaulting countries banks hold on average $9 \%$ of their assets in government bonds. Among countries that default at least once in our sample, this average is $13.5 \%$ in non-default years, and increases slightly to $14.5 \%$ of bank assets during default years.

\subsection{Summary statistics}

We consider the distribution of bank characteristics in BANKSCOPE, focusing on: (i) bank size as measured by total assets, (ii) non-cash assets (i.e. assets other than cash and other liquid securities), (iii) leverage as measured by one minus shareholders' equity as a share of assets, (iv) loans outstanding as a share of assets, (v) profitability as measured by operating

\footnotetext{
${ }^{9}$ To quantify the role of non-classical measurement error, write our bondholdings measure as $b=b^{*}+\delta$, where $b^{*}$ is true bonds and $\delta$ is measurement error. Denote by $\Delta l$ the change in lending during a given year of default. Measurement error is classical when $\operatorname{Cov}(\Delta l, \delta)=\operatorname{Cov}\left(b^{*}, \delta\right)=0$. In the Argentine default (2001-2004, 223 bank-year obs.) measurement error is not purely classical as $\operatorname{Cov}(\Delta l, \delta)=0.001781$ and $\operatorname{Cov}\left(b^{*}, \delta\right)=0.001669$. In $\operatorname{Section} 3$ we quantify the direction and the magnitude of the estimation distortions for the Argentine sub-sample.
} 
income over assets, (vi) exposure to the Central Bank as measured by deposits in the Central Bank over assets, (vii) balances in the interbank market, and (viii) government ownership, a dummy that equals one if the government owns more than $50 \%$ of the bank's equity. To neutralize the impact of outliers, all variables are winsorized at the 1st and 99th percentile. Panel B of Table 2 provides descriptive statistics for these variables in our sample. ${ }^{10}$ Table A1 in the online appendix reports the correlations between different bank characteristics in our sample.

\subsection{Sovereign default and macroeconomic conditions}

We proxy for sovereign defaults with a dummy variable based on Standard \& Poor's, which defines default as the failure of a government to meet a principal or interest payment on the due date (or within the specified grace period) contained in the original terms of the debt issue. According to this definition, our sample contains 20 defaults in 17 countries.

In our robustness tests, we complement our analysis by using two alternative measures of sovereign defaults, namely: (i) a monetary measure of creditors' losses given default, i.e., "haircuts", from the work of Cruces and Trebesch (2013) and Zettelmeyer et al. (2012), and; (ii) a market-based measure, whereby a country is defined to be in default either it satisfies the S\&P definition or if its sovereign bond spreads relative to the U.S. or German bonds exceed a given threshold (following the methodology of Pescatori and Sy, 2007).

Table A2 of the online appendix reports the defaults in our constant-continuing sample. There is a large variation in the size of defaulting countries and in the extent of bank coverage. To avoid picking up idiosyncratic features of default in countries that are small and have few banks, we show that our results are very similar across many subsamples. ${ }^{11}$

Data on the macroeconomic conditions of the different countries are obtained from the IMF's International Financial Statistics (IFS) and the World Bank's World Development Indicators (WDI). Table A3 in the online appendix describes all variables. To measure the size of financial markets we use the ratio of private credit provided by money deposit banks and other financial institutions to GDP, which is drawn from Beck et al. (2000). This widely used measure is an objective, continuous proxy for the size of the domestic credit markets.

\subsection{Sovereign bond returns}

Realized sovereign bond returns are obtained from J.P. Morgan's Emerging Market Bond Index Plus file (EMBIG + ) and from J.P. Morgan's Global Bond Index (GBI) file (see Kim, 2010 for a detailed description; see also Levy-Yeyati et al., 2010). ${ }^{12}$ Fig. 2 plots sovereign bond prices around default for the subsample of defaulting countries. It shows that bond prices drop very fast in the run-up to a sovereign default, with a substantial fraction of the drop concentrated in just a few months prior to the day of the default.

This J.P. Morgan data can be used to construct proxies for expected returns, which are not directly observable. We follow a standard two-step process. In the first step, bond returns are regressed on a set of country-specific economic, financial, and political risk factors:

$$
R_{c, t}=\gamma_{t}+\beta_{0}+\beta_{1} Z_{c, t-1}+u_{i, c, t},
$$

where $R_{c, t}$ is the realized return of government bonds in country $c$ at time $t, \gamma_{t}$ are time dummies (capturing variations in the global risk-free rate), and $Z_{c, t-1}$ is a vector of political, economic and financial risk ratings compiled by the International Country Risk Guide (henceforth, ICRG). ${ }^{13}$ In the second stage, expected returns are measured as the fitted values of this first-stage regression. Table A5 in the online appendix reports the results of the first-stage estimation of Eq. (1). There is a strong negative correlation between the risk ratings at time $t$ and realized returns at time $t+1$. Because these ratings are decreasing in risk, this result is consistent with theory: higher bond returns compensate investors for higher risk.

\section{Estimation results}

This section presents our regression results. Section 3.1 reports results on the relationship between sovereign defaults, bondholdings and loans. Section 3.2 analyzes banks' demand for bonds, in particular the extent to which these are purchased in normal times or in default years.

\footnotetext{
10 Panel $\mathrm{C}$ of Table 2 shows the characteristics of banks involved in the stress test. These banks are larger and extend more loans than the median BANKSCOPE bank. Leverage and cash are instead similar to the BANKSCOPE ones.

11 One concern here is that some small countries with few banks may drive our results (in eight defaulting countries our database covers five banks or less.). The second is that our results may only hold in large countries like Argentina and Russia. Our extensive robustness exercises show that our results do not depend on these particularities.

12 These indices aggregate the realized dollar returns of sovereign bonds of different maturities and denominations, assuming that coupons or pay downs are reinvested. They are available for 68 countries in our sample, covering 7 default episodes in 6 countries (Argentina, Russia Greece, Cote d'Ivoire, Ecuador, and Nigeria). Thus, using bond returns reduces sample size. Table A4 in the online appendix contains descriptive statistics on bond returns.

13 See Comelli (2012) for a similar method.
} 


\section{Daily Sovereign Bond Prices in Six Defaulting Countries}

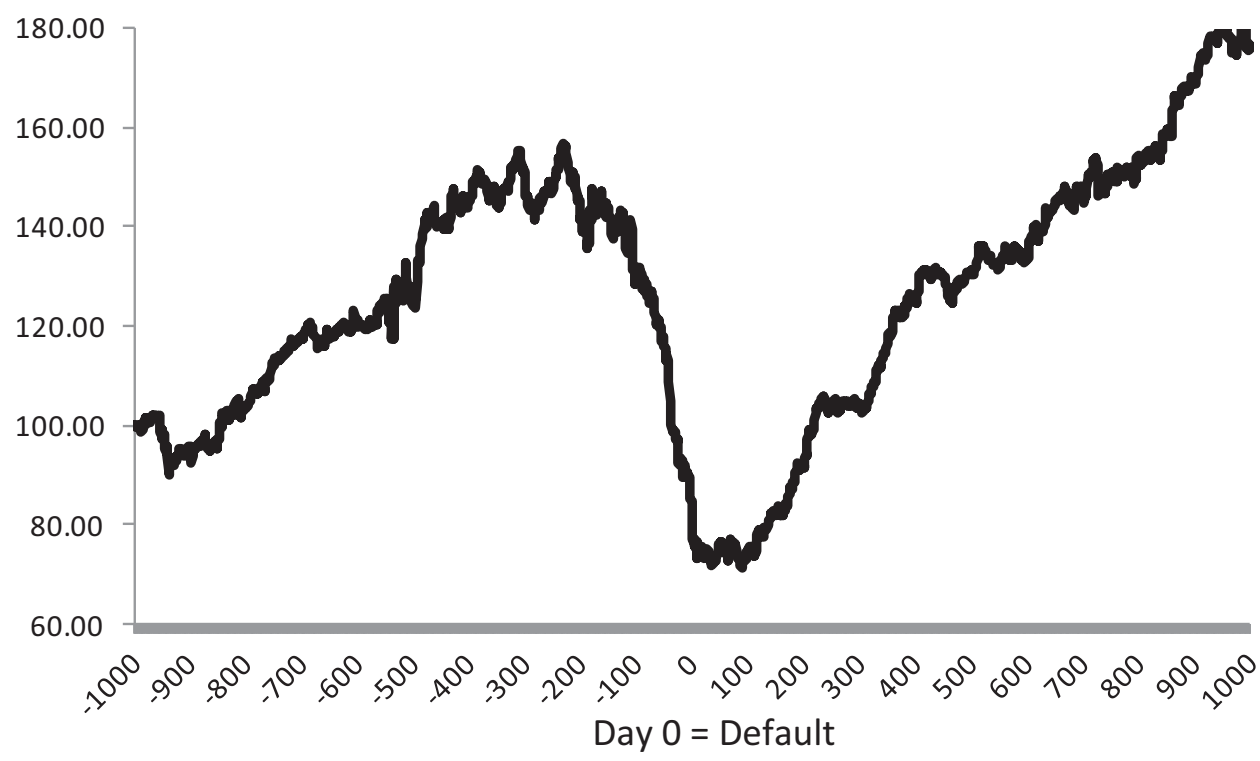

Fig. 2. Sovereign Bond Prices in Defaulting Countries. The figure plots the average bond prices over 7 default episodes in 6 countries (Argentina 2001-2004, Russia 1998-2000, Cote d'Ivoire 2000-2004, Ecuador 1998-2000, Ecuador 2009, Nigeria 2002, Greece 2012), from day $-1,000$ to $+1,000$, whereby day 0 is the day in which default is announced.

\subsection{Defaults, bondholdings and loans}

As a first step, we use our data to assess the correlation between a bank's bondholdings and its lending during default events. Let $\Lambda_{\mathrm{i}, \mathrm{c}, \mathrm{t}}$ denote the change in the loans-to-assets ratio of bank $i$, in country $c$, between years $t-1$ and $t$, and; let $B_{i, c, t-1}$ denote the bonds to assets ratio of bank $i$, in country $c$, in year $t-1$. Our most basic test is the following regression:

$$
\Lambda_{\mathrm{i}, \mathrm{c}, \mathrm{t}}=\gamma_{0}+\gamma_{1} \cdot B_{i, c, t-1}+\gamma_{2} \cdot \operatorname{Def} f_{c, t-1}+\gamma_{3} \cdot \operatorname{Def} f_{c, t-1} \cdot B_{i, c, t-1}+\gamma_{4} \cdot L_{i, c, t-1}+\gamma_{5} \cdot \operatorname{Def} f_{c, t-1} \cdot L_{i, c, t-1}+\mu_{i, c, t},
$$

where $D e f_{c, t-1}$ is a dummy variable taking value 1 if country $c$ is in default at $t-1$ and value 0 otherwise, and $L_{i, c, t-1}$ is the bank's loan-to-asset ratio that controls for the initial level of lending. This specification offers our minimal benchmark for quantification. We also run versions of Eq. (2) that include country dummies, time dummies, the interaction between both, and a large set of bank characteristics (alone and interacted with default) to control for banks' potentially different business models. Standard errors are clustered at the bank level throughout (clustering errors at the country level yields very similar results).

The coefficient of interest is $\gamma_{3}$. A negative value of $\gamma_{3}$ indicates that, ceteris paribus, banks holding more sovereign bonds extend fewer loans during sovereign defaults. Table 3 reports our estimates. Column 1 reports our baseline estimate of Eq. (2). The estimate for $\gamma_{3}$ is negative and significant, indicating that a bank's holdings of sovereign bonds are negatively associated with its lending during sovereign defaults.

The results do not change when we introduce time dummies in column 2 and country dummies in column 3. Column 4 presents a more stringent test, which includes in our regressions also the interaction of country and time dummies. By doing so, we effectively control for any country-specific shocks such as recessions, exchange rate devaluations, etc., that may cause both a government default and a drop in the demand for credit. The inclusion of country*time dummies more than doubles the R-squared. Consistent with intuition, country-specific, time-varying shocks are important determinants of bank lending. At the same time, our main coefficient remains robust. Within the same defaulting country-year, it is the banks most loaded with government bonds that reduce their lending the most. This is confirmed in column 5 when we control for a large set of bank-level characteristics. ${ }^{14}$

\footnotetext{
${ }^{14}$ It is possible to quantify non-classical measurement error for the Argentine default (2001-2004, 223 bank-year obs.). To do this, write bondholdings as $b=b^{*}+\delta$, where $b^{*}$ is true bonds and $\delta$ is measurement error. Denote by $\Delta l_{t}$ the change in lending from $t-1$ to $t$ during default. By regressing $\Delta l_{t}$ on $b_{t-1}$ and $l_{t-1}$, the coefficient $\beta$ on $b_{t-1}$, is: $\beta=\beta^{*} \frac{\operatorname{var}\left(l_{t-1}\right) \operatorname{var}\left(b_{t-1}^{*}\right)-\operatorname{cov}\left(b_{t-1}^{*}, l_{t-1}\right)^{2}}{\operatorname{var}\left(t_{t-1}\right) \operatorname{var}\left(b_{t-1}\right)-\operatorname{cov}\left(b_{t-1}, l_{t-1}\right)^{2}}+\frac{\operatorname{var}\left(l_{t-1}\right) \operatorname{cov}\left(\Delta t_{t}, \delta_{t-1}\right)-\operatorname{cov}\left(l_{t-1}, \delta_{t-1}\right) \operatorname{cov}\left(\Delta l_{t}, l_{t-1}\right)}{\operatorname{var}\left(l_{t-1}\right) \operatorname{var}\left(b_{t-1}\right)-\operatorname{cov}\left(b_{t-1}, l_{t-1}\right)^{2}}$ (3) where $\beta^{*}$ is the true coefficient. In the sub-sample of Argentine banks during the 2001-2004 default, the coefficient estimated with Bankscope data is $\beta=-0.152$, while the coefficient estimated using the "true" bondholdings measure of the Central Bank Argentina is $\beta^{*}=-0.774$. Intuitively, in the Argentine data the effect of classical measurement dominates and it results in a significant downward bias of our estimate.
} 
Table 3

Bondholdings, Sovereign default, and changes in loans.

\begin{tabular}{|c|c|c|c|c|c|}
\hline & $(1)$ & $(2)$ & (3) & $(4)$ & (5) \\
\hline $\begin{array}{l}\text { Bank Bondholdings }_{i, c, t-1} * \\
\text { Sovereign Default }{ }_{c, t-1}\end{array}$ & $\begin{array}{l}-0.100^{* * *} \\
(0.031)\end{array}$ & $\begin{array}{l}-0.098^{* * *} \\
(0.031)\end{array}$ & $\begin{array}{l}-0.085^{* * *} \\
(0.029)\end{array}$ & $\begin{array}{l}-0.116^{* * *} \\
(0.035)\end{array}$ & $\begin{array}{l}-0.133^{* * *} \\
(0.045)\end{array}$ \\
\hline Bank Bondholdings $_{i, c, t-1}$ & $\begin{array}{l}0.038^{* * *} \\
(0.005)\end{array}$ & $\begin{array}{l}0.037^{* * *} \\
(0.005)\end{array}$ & $\begin{array}{l}0.023^{* * *} \\
(0.007)\end{array}$ & $\begin{array}{l}0.015^{* *} \\
(0.007)\end{array}$ & $\begin{array}{l}0.018^{* *} \\
(0.008)\end{array}$ \\
\hline Sovereign Default ${ }_{c, t-1}$ & $\begin{array}{l}0.061^{* * *} \\
(0.015)\end{array}$ & $\begin{array}{l}0.061^{* * *} \\
(0.015)\end{array}$ & $\begin{array}{l}0.063^{* * *} \\
(0.015)\end{array}$ & & \\
\hline $\begin{array}{l}\text { Loans }_{i, c, t-1}{ }^{*} \\
\quad \text { Sovereign Default } \\
c, t-1\end{array}$ & $\begin{array}{l}-0.117^{* * *} \\
(0.026)\end{array}$ & $\begin{array}{l}-0.117^{* * *} \\
(0.026)\end{array}$ & $\begin{array}{l}-0.139^{* * *} \\
(0.027)\end{array}$ & $\begin{array}{l}-0.162^{* * *} \\
(0.032)\end{array}$ & $\begin{array}{l}-0.189^{* * *} \\
(0.041)\end{array}$ \\
\hline Loans $_{i, c, t-1}$ & $\begin{array}{l}-0.047^{* * *} \\
(0.003)\end{array}$ & $\begin{array}{l}-0.048^{* * *} \\
(0.003)\end{array}$ & $\begin{array}{l}-0.057^{* * *} \\
(0.003)\end{array}$ & $\begin{array}{l}-0.052^{* * *} \\
(0.003)\end{array}$ & $\begin{array}{l}-0.049^{* * *} \\
(0.004)\end{array}$ \\
\hline $\begin{array}{l}\text { Bank Size }_{i, c, t-1} * \\
\quad \text { Sovereign Default } \\
c, t-1\end{array}$ & & & & & $\begin{array}{l}-0.001 \\
(0.003)\end{array}$ \\
\hline $\begin{array}{l}\text { Non-cash assets } \\
\text { Sovereign Default } \\
\text { Sctt-1 }\end{array}$ & & & & & $\begin{array}{l}0.030 \\
(0.107)\end{array}$ \\
\hline $\begin{array}{l}\text { Leverage }_{i, c, t-1} * \\
\quad \text { Sovereign Default } \\
c, t-1\end{array}$ & & & & & $\begin{array}{l}0.028 \\
(0.048)\end{array}$ \\
\hline $\begin{array}{l}\text { Profitability }_{i, c, t-1} * \\
\quad \text { Sovereign Default } \\
c, t-1\end{array}$ & & & & & $\begin{array}{l}-0.087 \\
(0.099)\end{array}$ \\
\hline $\begin{array}{l}\text { Exposure to Central Bank } k_{i, c, t-1} * \\
\text { Sovereign Default } \\
c, t-1\end{array}$ & & & & & $\begin{array}{l}-0.155 \\
(0.095)\end{array}$ \\
\hline $\begin{array}{l}\text { Interbank Balances }_{i, c, t-1} * \\
\text { Sovereign Default } \\
c, t-1\end{array}$ & & & & & $\begin{array}{l}-0.009 \\
(0.053)\end{array}$ \\
\hline $\begin{array}{l}\text { Government Owned } \\
\text { Sovereign Default } \\
\text { Sc,t-1 }\end{array}$ & & & & & $\begin{array}{l}-0.008 \\
(0.017)\end{array}$ \\
\hline Bank Size $_{i, c, t-1}$ & & & & & $\begin{array}{l}0.001^{* * *} \\
(0.000)\end{array}$ \\
\hline Non-cash assets $s_{i, c, t-1}$ & & & & & $\begin{array}{l}-0.021 \\
(0.016)\end{array}$ \\
\hline Leverage $_{i, c, t-1}$ & & & & & $\begin{array}{l}-0.003 \\
(0.009)\end{array}$ \\
\hline Profitability $_{i, c, t-1}$ & & & & & $\begin{array}{l}-0.087^{* *} \\
(0.042)\end{array}$ \\
\hline Exposure to Central Bank ${ }_{i, c, t-1}$ & & & & & $\begin{array}{l}0.047^{* * *} \\
(0.016)\end{array}$ \\
\hline Interbank Balances $_{i, c, t-1}$ & & & & & $\begin{array}{l}0.004 \\
(0.005)\end{array}$ \\
\hline Government Owned $_{i, c, t-1}$ & & & & & $\begin{array}{l}-0.001 \\
(0.003)\end{array}$ \\
\hline Year Dummies? & No & Yes & Yes & Yes & Yes \\
\hline Country Dummies? & No & No & Yes & Yes & Yes \\
\hline Country x Year Dummies? & No & No & No & Yes & Yes \\
\hline Constant & $\begin{array}{l}0.025^{* * *} \\
(0.002)\end{array}$ & $\begin{array}{l}0.025^{* * *} \\
(0.003)\end{array}$ & $\begin{array}{l}0.022 \\
(0.010)\end{array}$ & $\begin{array}{l}-0.080 \\
(.)\end{array}$ & $\begin{array}{l}-0.078 \\
(177.873)\end{array}$ \\
\hline No Observations & 27,408 & 27,408 & 27,408 & 27,408 & 27,408 \\
\hline No Banks & 5,218 & 5,218 & 5,218 & 5,218 & 5,218 \\
\hline No Countries & 158 & 158 & 158 & 158 & 158 \\
\hline R-squared & 0.037 & 0.042 & 0.081 & 0.221 & 0.224 \\
\hline
\end{tabular}

The table presents coefficient estimates from pooled OLS regressions. The dependent variable changes in loans is computed as loans outstanding divided by total assets in year $t$ minus loans outstanding divided by total assets in year $\mathrm{t}-1$. The main independent variables are bank bondholdings, computed as bondholdings divided by total assets, and an indicator for sovereign default. Standard errors (in parentheses below the coefficient estimates) are adjusted for heteroscedasticity using the Huber (1967) and White (1980) correction, as well as clustering at the bank level using the Huber (1967) correction. *** indicates significance at the $1 \%$ level; ** indicates significance at the $5 \%$ level; * indicates significance at the $10 \%$ level.

One remaining concern is that, within the same country-year, banks holding more government bonds may happen to have greater exposure to the country-level, time-varying macroeconomic shocks. For instance, these banks may be unhedged against macroeconomic shocks like currency devaluations, so their lending might drop because of the devaluation and not because of the bonds they hold. To assess this possibility, Table 4 adds to the regression of Table 3's column 5 the interaction between bank bondholdings and two major macroeconomic factors: a country's GDP growth and its exchange rate devaluation relative to the U.S. dollar. The interaction between bank bondholdings and sovereign default remains negative, statistically significant, and its magnitude is stable. The R-squared in all columns is very close to that of column 5 of Table 3 . Of the two macroeconomic shocks, only GDP growth has a significant (positive) effect on lending by banks holding more bonds. 
Table 4

Bondholdings, country shocks, and changes in loans.

\begin{tabular}{|c|c|c|c|c|}
\hline & $(1)$ & $(2)$ & $(3)$ & $(4)$ \\
\hline Bank Bondholdings $s_{t-1} *$ & $-0.144^{* *}$ & $-0.117^{* *}$ & $-0.131^{*}$ & $-0.107^{*}$ \\
\hline Sovereign Default ${ }_{t-1}$ & $(0.062)$ & $(0.047)$ & $(0.068)$ & $(0.064)$ \\
\hline Bank Bondholdings $_{t-1} *$ & 0.156 & $0.285^{* *}$ & & \\
\hline GDP Growth t-1 & $(0.140)$ & $(0.137)$ & & \\
\hline Bank Bondholdings $_{t-1} *$ & & & -0.027 & -0.025 \\
\hline Exchange Rate Devaluation $_{t-1}$ & & & $(0.040)$ & $(0.039)$ \\
\hline Sovereign Bond Return * & 0.091 & & -0.010 & \\
\hline Sovereign Default ${ }_{t-1}$ & $(0.077)$ & & $(0.059)$ & \\
\hline \multirow[t]{2}{*}{ Bank Bondholdings $s_{t-1}$} & 0.001 & 0.003 & 0.008 & 0.013 \\
\hline & $(0.012)$ & $(0.009)$ & $(0.011)$ & $(0.008)$ \\
\hline Bank-Level Controls and Interactions with Sovereign Default? & Yes & Yes & Yes & Yes \\
\hline Bank-Level Controls and Interactions with GDP Growth? & Yes & Yes & & \\
\hline Bank-Level Controls and Interactions with Exchange Rate Devaluation? & & & Yes & Yes \\
\hline Year Dummies? & Yes & Yes & Yes & Yes \\
\hline Country Dummies? & Yes & Yes & Yes & Yes \\
\hline Country * Year Dummies? & Yes & Yes & Yes & Yes \\
\hline \multirow[t]{2}{*}{ Constant } & 0.229 & -0.040 & -0.118 & 0.141 \\
\hline & $(0.147)$ & $(3.715)$ & $(0.087)$ & $(130.540)$ \\
\hline No Observations & 13,873 & 26,467 & 13,908 & 24,982 \\
\hline No Banks & 3,649 & 4,967 & 3,646 & 4,645 \\
\hline No Countries & 56 & 129 & 54 & 97 \\
\hline R-squared & 0.205 & 0.214 & 0.205 & 0.204 \\
\hline
\end{tabular}

The table presents coefficient estimates from pooled OLS regressions. The dependent variable changes in loans is computed as loans outstanding in year $\mathrm{t}$ minus loans outstanding in year $\mathrm{t}-1$, divided by total assets. The main independent variables are bank bondholdings, computed as bondholdings divided by total assets, an indicator for sovereign default, GDP annual percent growth, and exchange rate devaluation, computed as percent change in the exchange rate with the US dollar. Standard errors (in parentheses below the coefficient estimates) are adjusted for heteroscedasticity using the Huber (1967) and White (1980) correction, as well as for clustering at the bank level using the Huber (1967) correction. ${ }^{* * *}$ indicates significance at the $1 \%$ level; ** indicates significance at the $5 \%$ level; * indicates significance at the $10 \%$ level.

Table 5 reports further robustness checks that consider different subsamples and alternative definitions of defaults. Columns 1 and 2 exclude government-owned banks from the sample, for the behavior of these banks may be distorted by politics. Columns 3 and 4 focus on the largest defaults by GDP per capita, number of banks involved, and dollar value of restructured debt, namely, Argentina, Greece, Russia, and Ukraine. Columns 5-10 exclude defaulting countries with fewer than 5,10 , and 15 banks. Throughout, the results are robust and point estimates are stable, suggesting that they are unlikely to be driven by severe omitted variables or special subsamples. Additionally, columns 11-14 show that the results survive under alternative definitions of defaults such as: (i) the haircut measure of default constructed by Cruces and Trebesch (2013) and Zettelmeyer et al. (2012), which measures the severity of a default, and; (ii) the augmented measure that adds to the S\&P default dummy also events in which sovereign spreads exceed 1,000 basis points. ${ }^{15}$

We also consider alternative measures of bank lending. Because changes in the loans-to-assets ratio may reflect changes in total assets, our previous results may pick up deleveraging. We thus estimate two alternatives to Eq. (2), where the dependent variables are respectively given by

$$
\left(\frac{\mathrm{L}_{\mathrm{i}, \mathrm{c}, \mathrm{t}}-\mathrm{L}_{\mathrm{i}, \mathrm{c}, \mathrm{t}-1}}{\mathrm{~A}_{\mathrm{i}, \mathrm{c}, \mathrm{t}-1}}\right) \text { and } \Delta \log \left(\mathrm{L}_{\mathrm{i}, \mathrm{c}, \mathrm{t}}\right) \text {, }
$$

i.e., the change in loans divided by lagged assets and the growth rate of loans (e.g., see Kashyap and Stein, 2000). All righthand side variables are the same as in Eq. (2). We present the results from these alternative specifications in Panels $A$ and $\mathrm{B}$ of Table A6 in the online appendix, respectively. Our results are confirmed. If anything, they become stronger.

In sum, consistent with the supply channel hypothesis, a bank's holding of sovereign bonds is robustly associated with a decline in its lending during sovereign defaults. This association, moreover, is quantitatively large. Consider the following back-of-the-envelope calculation based on the baseline specification in column 1 of Table 3: relative to a bank that holds no public bonds, a bank with the average bonds-to-assets ratio of $14.49 \%$ experiences an additional fall in the loans-to-assets ratio of one percentage point. For a given growth rate of assets, this implies that the growth rate of lending of a bank with average bondholdings is 2 percentage points below that of a bank with no bonds. But since the assets of banks with average bondholdings also grow less than those of banks that hold no bonds during default years, our estimates imply that banks with average bondholdings experience an overall 7 percentage-point lower lending growth. ${ }^{16}$

\footnotetext{
15 The paucity of data on spreads limits this exercise to the larger, economically more important defaults. The additional defaults examined here are Ireland in 2011, Portugal 2011 and 2012, Greece in 2011, and Ukraine in 2001.

${ }^{16}$ To see the logic of the quantification, note that in column 1 of Table 3 the drop in the loans-to-assets ratio for a bank holding the average amount of bonds relative to a bank holding no bonds is $(0.038-0.1) *(0.145)=-0.009$ (where 0.145 are the bonds held by the average bank in default). This effect
} 
Table 5

Bondholdings, Sovereign default, and changes in loans: Robustness tests.

\begin{tabular}{|c|c|c|c|c|c|c|c|c|c|c|c|c|c|c|}
\hline & \multicolumn{2}{|c|}{$\begin{array}{l}\text { Exclude government } \\
\text { owned banks }\end{array}$} & \multicolumn{2}{|c|}{ Largest defaults only } & \multicolumn{2}{|c|}{$\begin{array}{l}\text { No defaults with }<5 \\
\text { banks }\end{array}$} & \multicolumn{2}{|c|}{$\begin{array}{l}\text { No defaults with }<10 \\
\text { banks }\end{array}$} & \multicolumn{2}{|c|}{$\begin{array}{l}\text { No defaults with }<15 \\
\text { banks }\end{array}$} & \multicolumn{2}{|c|}{$\begin{array}{l}\text { Haircut measure of } \\
\text { default }\end{array}$} & \multicolumn{2}{|c|}{$\begin{array}{l}\text { Spread or Default } \\
\text { measure of default }\end{array}$} \\
\hline & $\overline{(1)}$ & (2) & (3) & (4) & $(5)$ & (6) & $(7)$ & (8) & (9) & (10) & $(11)$ & (12) & $(13)$ & (14) \\
\hline $\begin{array}{l}\text { Bank Bondholdings } s_{t-1} * \\
\text { Sovereign Default }\end{array}$ & $\begin{array}{l}-0.101^{*} \\
(0.058)\end{array}$ & $\begin{array}{l}-0.128^{* * *} \\
(0.047)\end{array}$ & $\begin{array}{l}-0.195^{* * *} \\
(0.060)\end{array}$ & $\begin{array}{l}-0.231^{* * *} \\
(0.060)\end{array}$ & $\begin{array}{l}-0.096^{*} \\
(0.058)\end{array}$ & $\begin{array}{l}-0.132^{* * *} \\
(0.046)\end{array}$ & $\begin{array}{l}-0.150^{* * *} \\
(0.057)\end{array}$ & $\begin{array}{l}-0.160^{* * *} \\
(0.046)\end{array}$ & $\begin{array}{l}-0.150^{* * *} \\
(0.057)\end{array}$ & $\begin{array}{l}-0.179^{* * *} \\
(0.047)\end{array}$ & $\begin{array}{l}-0.242^{* * *} \\
(0.081)\end{array}$ & $\begin{array}{l}-0.256^{* * *} \\
(0.067)\end{array}$ & $\begin{array}{l}-0.129 * * \\
(0.052)\end{array}$ & $\begin{array}{l}-0.156^{* * *} \\
(0.054)\end{array}$ \\
\hline $\begin{array}{l}\text { Sovereign Bond Return }{ }_{t-1} \\
\text { Sovereign Default }_{t-1}\end{array}$ & $\begin{array}{l}0.075^{* * *} \\
(0.016)\end{array}$ & & $\begin{array}{l}0.062^{* * *} \\
(0.015)\end{array}$ & & $\begin{array}{l}0.071^{* * *} \\
(0.015)\end{array}$ & & $\begin{array}{l}0.046^{* * *} \\
(0.014)\end{array}$ & & $\begin{array}{l}0.045^{* * *} \\
(0.014)\end{array}$ & & $\begin{array}{l}0.130^{* * *} \\
(0.026)\end{array}$ & & $\begin{array}{l}0.062^{* * *} \\
(0.015)\end{array}$ & \\
\hline Sovereign Default $t_{t-1}$ & $\begin{array}{l}-0.021 \\
(0.023)\end{array}$ & & $\begin{array}{l}0.002 \\
(0.032)\end{array}$ & & $\begin{array}{l}-0.007 \\
(0.031)\end{array}$ & & $\begin{array}{l}0.023 \\
(0.035)\end{array}$ & & $\begin{array}{l}0.023 \\
(0.035)\end{array}$ & & $\begin{array}{l}-0.044 \\
(0.265)\end{array}$ & & $\begin{array}{l}-0.006 \\
(0.131)\end{array}$ & \\
\hline Sovereign Bond Return $n_{t-1}$ & $\begin{array}{l}0.003 \\
(0.007)\end{array}$ & & $\begin{array}{l}0.008 \\
(0.008)\end{array}$ & & $\begin{array}{l}0.003 \\
(0.007)\end{array}$ & & $\begin{array}{l}0.016^{* *} \\
(0.007)\end{array}$ & & $\begin{array}{l}0.017^{* *} \\
(0.007)\end{array}$ & & $\begin{array}{l}0.001 \\
(0.007)\end{array}$ & & $\begin{array}{l}0.007 \\
(0.007)\end{array}$ & \\
\hline $\begin{array}{l}\text { Bank-Level Controls and } \\
\text { Interactions? }\end{array}$ & Yes & Yes & Yes & Yes & Yes & Yes & Yes & Yes & Yes & Yes & Yes & Yes & Yes & Yes \\
\hline Year Dummies? & Yes & Yes & Yes & Yes & Yes & Yes & Yes & Yes & Yes & Yes & Yes & Yes & Yes & Yes \\
\hline Country Dummies? & Yes & Yes & Yes & Yes & Yes & Yes & Yes & Yes & Yes & Yes & Yes & Yes & Yes & Yes \\
\hline Country x Year Dummies? & & Yes & & Yes & & Yes & & Yes & & Yes & & Yes & & Yes \\
\hline Constant & $\begin{array}{l}-0.006 \\
(0.021)\end{array}$ & $\begin{array}{l}-0.032 \\
(101.8)\end{array}$ & $\begin{array}{l}-0.031 \\
(0.022)\end{array}$ & $\begin{array}{l}-0.109 * * * \\
(0.040)\end{array}$ & $\begin{array}{l}-0.025 \\
(0.021)\end{array}$ & $\begin{array}{l}0.040 \\
(0.057)\end{array}$ & $\begin{array}{l}-0.066^{* *} \\
(0.027)\end{array}$ & $\begin{array}{l}0.089 * \\
(0.054)\end{array}$ & $\begin{array}{l}-0.056^{* *} \\
(0.027)\end{array}$ & $\begin{array}{l}-0.154^{* * *} \\
(0.017)\end{array}$ & $\begin{array}{l}-0.035 \\
(0.029)\end{array}$ & $\begin{array}{l}-0.081 \\
(106.077)\end{array}$ & $\begin{array}{l}-0.024 \\
(.)\end{array}$ & $\begin{array}{l}0.191 * * * \\
(0.020)\end{array}$ \\
\hline No Observations & 13,726 & 26,570 & 13,415 & 26,059 & 14,035 & 27,218 & 13,624 & 26,786 & 13,494 & 26,576 & 17,923 & 31,431 & 17,296 & 30,076 \\
\hline No Banks & 3,634 & 5,049 & 3,388 & 4,729 & 3,532 & 4,923 & 3,445 & 4,835 & 3,396 & 4,784 & 5,343 & 6,768 & 5,396 & 6,770 \\
\hline No Countries & 60 & 158 & 55 & 147 & 58 & 151 & 55 & 148 & 54 & 147 & 61 & 160 & 56 & 160 \\
\hline R-squared & 0.106 & 0.225 & 0.119 & 0.226 & 0.105 & 0.220 & 0.119 & 0.222 & 0.119 & 0.221 & 0.110 & 0.216 & 0.119 & 0.218 \\
\hline
\end{tabular}

The table presents coefficient estimates from pooled OLS regressions. The dependent variable changes in loans is computed as loans outstanding in year $t$ minus loans outstanding in year t-1, divided by total assets. The main independent variables are bank average non-default years bondholdings, computed as the average of bank bondholdings in all the non-default years prior to and including year $t-1$, bank time-varying bondholdings, computed as bank bondholdings minus bank average non-default years bondholdings. Largest defaults are Argentina’s, Russia's Ukraine's and Greece's. Standard errors (in parentheses

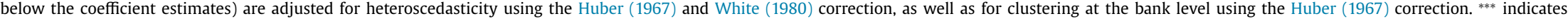
significance at the $1 \%$ level; ** indicates significance at the $5 \%$ level; * indicates significance at the $10 \%$ level. 
Having established that our baseline results are robust and large, we now exploit the cross-country dimension of our data to examine how they depend on key country-characteristics, like the type of exchange-rate regime, the level of development, and the quality of financial, economic and legal institutions. To assess the role of the exchange-rate regime, Eq. (2) is separately estimated in countries that have a hard exchange-rate peg, a soft exchange-rate peg, and no peg, according to the classification proposed by Shambaugh (2004). ${ }^{17}$ To assess the role of economic development, Eq. (2) is separately estimated in subsamples of countries with high (\$35 K per year, measured in 2010 USD), middle (between $\$ 7 \mathrm{~K}$ and $\$ 35 \mathrm{~K}$ ), and low (below $\$ 7 \mathrm{~K}$ ) average per-capita income. To assess the role of financial institutions-as measured by the Djankov et al. (2007) creditor rights score, which ranges between 0 (lowest) and 4 (highest)-Eq. (2) is separately estimated in subsamples of countries that exhibit on average a high (an average score above 2), medium (an average score of 2), or low (an average score below 2) score on this index. To assess the role of economic and political institutions we use the ICRG (2013) scores of economic and political risk, which range from 0 to 50 (lowest economic risk) and 100 (lowest political risk), respectively. For each type of risk, we split the sample in three sub-samples of countries, with high (score above 40 or 80 , respectively), medium or low (score below 35 or 65 , respectively) institutional quality. ${ }^{18}$

Table 6 below reports, for each policy or institutional variable, the coefficient $\gamma_{3}$ of the default-bondholdings interaction estimated within each of the three groups of countries. Once again, these exercises cannot provide causal identification but offer stylized facts that quantitative theories may seek to target.

The association between post-default decline in lending and bank bondholdings appears to be stronger in countries that have pegged exchange rates relative to countries that have a soft peg or no peg at all. Regarding economic, financial, and political variables, this association also tends to be stronger in countries with medium (as opposed to low) economic and institutional development, as measured through all our indicators except for creditor rights (where the difference between groups is not significant). This is consistent with the notion that financial intermediation may play a larger economic role in middle-income countries, which makes them more vulnerable to disruption by sovereign crises (e.g., Gennaioli et al., 2014).

To conclude, we wish to note that our findings on the association between bank lending and bondholdings could be due to both the bonds bought by a bank well before a sovereign default and those potentially bought in the run-up to the crisis and during the crisis itself. The latter is consistent with the "risk-taking" mechanism emphasized during the recent European crisis. To assess this possibility, we run modified versions of Equation (3), in which we replace our measure of a bank's bondholdings $B_{i, c, t-1}$ with alternative measures that reflect the bonds held by the bank in normal times, before default occurs.

We first run a cross sectional version of Eq. (2) in which we regress the change in a bank's loans to assets ratio occurring during the first two years of default on its bondholdings in the year before default. The regression includes country and year dummies. Estimation results are reported in column 1 of Table 7 . Bonds held in the year before default have a negative association with changes in lending during the first two years of the default episode. The point estimate is slightly more than twice as large as the one obtained in Table 4, so that - on a per-year basis - the result is close to the upper bound of our previous estimates.

One concern with the specification of column 1 is that a bank's holdings of sovereign bonds in the year prior to default may already reflect an increase in sovereign risk. This seems unlikely, given that - as shown by Fig. 2- bond returns spike in close proximity to the moment of default. In any event, column 2 addresses this concern by using a more conservative proxy of normal-times bonds: the average holdings in the three years prior to the onset of default. The previous results are confirmed. ${ }^{19}$

In sum, there is a strong and negative correlation between a bank's bondholdings at the time of default and its subsequent lending. Although this evidence is strongly consistent with the supply channel, it falls short of perfectly identifying it. First, although we control for all aggregate shocks, our bank-level data do not allow us to control for all heterogeneity among banks in reaction to these shocks. A recent literature relies on natural experiments and on matched bank-firm-loan level data to precisely identify supply effects, although often at the cost of focusing on a single (emerging) country. ${ }^{20}$ The fact that our results are very robust to accounting for all observable bank characteristics, however, is reassuring. Second, we saw that the BANKSCOPE data do not allow us to measure banks' domestic exposure in a precise manner. Our analysis of Section 2.2, however, indicates that the BANKSCOPE measure is a very good proxy for cross-bank variation in domestic expo-

alone corresponds to a lower growth rate of loans of $0.009 *\left(\frac{A_{t}}{L_{t-1}}\right)=0.009 * 2.2=0.02$. Then, because exposed banks exhibit-for a given loans-to-asset ratio-a 5 percentage-point lower growth rate of assets during default, their growth rate of loans is $2+5=7$ percentage points lower. These estimates line up well with those in Table A6, where we find that in default years total lending of banks holding average bonds grows by 5.5 percentage points less than that of banks with no bonds.

17 In our defaulting countries the exchange rate regime is stable in the years before, during and after default.

18 These subsamples were designed to have a roughly equal number of observations in the middle and bottom group. The top category of developed economies is the largest group, as it contains between $60 \%$ and $66 \%$ of all observations. These countries are in a separate category because there is virtually no default there. Two exceptions are Kenya and Nigeria in the creditor rights split: they both default and attain a maximum score of 4 . On the other hand, the medium and low sub-samples in which most sovereign defaults occur roughly correspond to middle income versus poor countries. These two groups have similar numbers of bank-year observations.

19 As these tests require consecutive bank data for a five-year window around a default, they effectively focus on large banks in large defaulting countries such as for example Argentina, Greece, and Ecuador.

20 See Khwaja and Mian (2008) on Pakistan, Paravisini (2008) on Argentina, Schnabl (2012) on Peru, Jimenez, Ongena, Peydro, and Saurina (2012) on Spain, Amiti and Weinstein (2011) on Japan, Paravisini, Rappoport, Schnabl, and Wolfenzon (2014) on Peru, Iyer, Lopes, Peydro and Schoar (2014) on Portugal. 
Table 6

Bondholdings, Sovereign Default, and changes in loans: Cross-country variation.

\begin{tabular}{|c|c|c|}
\hline Peg & $\begin{array}{l}\text { Exchange Rate Policy } \\
\text { Soft Peg }\end{array}$ & No Peg \\
\hline $\begin{array}{l}-0.230^{* *} \\
(0.106)\end{array}$ & $\begin{array}{l}-0.085^{* *} \\
(0.040)\end{array}$ & $\begin{array}{l}-0.085^{*} \\
(0.049)\end{array}$ \\
\hline High & $\begin{array}{l}\text { GDP per capita } \\
\text { Medium }\end{array}$ & Low \\
\hline $\mathrm{N} / \mathrm{A}$ & $\begin{array}{l}-0.190^{* * * *} \\
(0.054)\end{array}$ & $\begin{array}{l}-0.042 \\
(0.029)\end{array}$ \\
\hline High & $\begin{array}{l}\text { Creditor Rights } \\
\text { Medium }\end{array}$ & Low \\
\hline $\begin{array}{l}-0.072^{* *} \\
(0.033)\end{array}$ & $\begin{array}{l}-0.169 * * * \\
(0.065)\end{array}$ & $\begin{array}{l}-0.159^{* * *} \\
(0.052)\end{array}$ \\
\hline High & $\begin{array}{l}\text { Economic Institutions } \\
\text { Medium }\end{array}$ & Low \\
\hline $\mathrm{N} / \mathrm{A}$ & $\begin{array}{l}-0.129 * * \\
(0.060)\end{array}$ & $\begin{array}{l}-0.043 \\
(0.030)\end{array}$ \\
\hline High & $\begin{array}{l}\text { Political Institutions } \\
\text { Medium }\end{array}$ & Low \\
\hline $\mathrm{N} / \mathrm{A}$ & $\begin{array}{l}-0.122^{* *} \\
(0.056)\end{array}$ & $\begin{array}{l}-0.059^{*} \\
(0.031)\end{array}$ \\
\hline
\end{tabular}

The table presents coefficient estimates of the main independent variable from pooled OLS regressions. The dependent variable changes in loans is computed as loans outstanding divided by total assets in year $\mathrm{t}$ minus loans outstanding divided by total assets in year $\mathrm{t}-1$. The main independent variables are bank bondholdings, computed as bondholdings divided by total assets, and an indicator for sovereign default. The other independent variable are loans divided by assets, and the interaction of sovereign default and loans. Regression specifications include also year and country fixed effects. Standard errors (in parentheses below the coefficient estimates) are adjusted for heteroscedasticity using the Huber (1967) and White (1980) correction, as well as for clustering at the bank level using the Huber (1967) correction. *** indicates significance at the $1 \%$ level; ${ }^{* *}$ indicates significance at the $5 \%$ level; * indicates significance at the $10 \%$ level. N/A indicates no default observations for the corresponding group of countries. Exchange rate policy data use the Shambaugh (2004) definitions of peg and soft peg. GDP per capita is obtained from the World Development Indicator; High corresponds to an average annual income above $\$ 35 \mathrm{~K}$ (measured in 2010 USD), Medium to an average annual income between $\$ 7 \mathrm{~K}$ and $\$ 35 \mathrm{~K}$, and Low to an average annual income below $\$ 7 \mathrm{~K}$. Creditor Rights is the score of Djankov et al. (2007), where High is a score above 2, Medium is a score of 2, and Low is a score below 2. Economic Institutions is the economic score from ICRG (2013): High is a score above 40, Medium is a score between 35 and 40 , Low is a score below 35 . Political Institutions is the political score from (2013): High is a score above 80, Medium is a score between 65 and 80, Low is a score below 65 .

sure, at least for two recent and important episodes of heightened sovereign risk (the EU during 2010-2012, and Argentina 1997-2004). Often, moreover, home bias tends to increase in times of crisis, in which case our bondholdings measure - and its association with lending, which is the main object of this section - should be most accurate precisely during default episodes. ${ }^{21}$

But what determines a bank's bondholdings in the first place? This question speaks to (i) the origins of the "dangerous embrace" of banks and governments, and to (ii) the endogeneity of bondholdings to bank characteristics and country shocks. We now address this question.

\footnotetext{
21 For evidence of increases in home bias during crises, see Broner, Didier, Erce, and Schmukler (2013).
} 
Table 7

Bondholdings and changes in loans: Normal times $\mathrm{v}$ default years bonds.

\begin{tabular}{lll}
\hline & $(1)$ & $(2)$ \\
\hline Pre-Default Bank Bondholdings & $-0.281^{* * *}$ & \\
& $(0.080)$ & $-0.361^{* * *}$ \\
Avg Pre-Default Bank Bondholdings & & $(0.028)$ \\
& & Yes \\
Bank-Level Controls and Interactions? & Yes & Yes \\
Year Dummies? & Yes & Yes \\
Country Dummies? & Yes & $0.874^{* *}$ \\
Country x Year Dummies? & & $(0.272)$ \\
Constant & $0.780^{* *}$ & 105 \\
& $(0.275)$ & 105 \\
\hline No Observations & 105 & 5 \\
No Banks & 105 & 0.442 \\
No Countries & 5 & 0.439 \\
R-squared & 0.49 & . \\
\hline
\end{tabular}

The table presents coefficient estimates from pooled OLS regressions. The dependent variable changes in loans is computed as loans outstanding in year $t$ minus loans outstanding in year $\mathrm{t}-1$, divided by total assets. The main independent variables are predefault bank bondholdings, computed as bondholdings in the year prior to the first year of a sovereign default, divided by total assets; average pre-default bank bondholdings, computed as the average of bondholdings divided by total assets in the last three years prior to the first year of a sovereign default. Standard errors (in parentheses below the coefficient estimates) are adjusted for heteroscedasticity using the Huber (1967) and White (1980) correction, as well as for clustering at the bank level using the Huber (1967) correction. ${ }^{* * *}$ indicates significance at the $1 \%$ level; ${ }^{* *}$ indicates significance at the $5 \%$ level; * indicates significance at the $10 \%$ level.

\subsection{Determinants of Banks' bondholdings}

Let $B_{i, c, t}$ denote the ratio of government bonds over assets held in year $t$, by bank $i$ located in country $c$. We think of $B_{i, c, t}$ as being chosen by bank $i$ at $t-1$ and, to study its determinants, we run the following regression:

$$
B_{i, c, t}=\alpha_{0}+\alpha_{1} \cdot X_{i, c, t-1}+\alpha_{2} \cdot X_{c, t-1}+\alpha_{3} \cdot D e f_{c, t-1}+\alpha_{4} \cdot D e f_{c, t-1} \cdot X_{i, c, t-1}+\alpha_{5} \cdot D e f_{c, t-1} \cdot X_{c, t-1}+\epsilon_{i, c, t},
$$

where $D e f_{c, t-1}$ is our default dummy. We estimate Eq. (5) in specifications that include country dummies, time dummies, and their interaction. Standard errors are clustered at the bank level.

Vector $X_{i, c, t-1}$ includes bank characteristics that may affect the demand for bonds, such as loans outstanding (which proxies for a bank's investment opportunities), non-cash assets, exposure to central bank, interbank balances, profitability, size, and whether or not the bank is owned by the government. Lagged bondholdings are also included to control for persistence. Vector $X_{c, t-1}$ includes country-level factors such as financial development (as measured by Private Credit to GDP and banking crises), GDP growth, inflation, and exchange-rate depreciation. We also control for the expected return of domestic bonds $R_{c, t}^{e}$, which captures the expectation (at time $t-1$ ) of the time- $t$ return of government bonds of country $c$. As explained in Section 2, we fit this variable by using GMM to regress realized returns on country-specific risk factors.

Coefficients $\alpha_{1}$ and $\alpha_{2}$, respectively, capture the effect of bank- and country-factors on a bank's holdings of government bonds outside of default episodes (i.e., in "normal times" ). Coefficients $\alpha_{3}, \alpha_{4}$ and $\alpha_{5}$ capture the change in the demand for bonds during default episodes, allowing such change to be heterogeneous across banks and countries. Eq. (5) allows us to test whether bondholdings behave differently in years of default relative to all other years. If $\alpha_{3}>0$, for instance, all banks tend to increase their bondholdings during default events.

Table 8 reports the estimates of different specifications of Eq. (5). Column 1 includes only time dummies. The demand for bonds in normal times exhibits two features. First, it is decreasing in outstanding loans, presumably because banks with more investment opportunities do not need to store their funds in public bonds. Second, bondholdings are also lower in more financially developed countries (i.e. those sustaining a high Private Credit/GDP ratio and not experiencing a banking crisis). Larger banks seem to hold more bonds in normal times, but this result is not robust across specifications.

Consider next how the patterns of bondholdings change during default events. This is captured by the coefficients of the default dummy, both alone and interacted with bank and country characteristics. The default dummy is insignificant, and it is bank- and country-characteristics that determine which banks purchase bonds during crises. The interaction between bank size and the default dummy suggests that large banks disproportionally accumulate government bonds during default. In fact, it is the concentration of bonds into large banks that accounts for the slight increase in bondholdings that is observed in our sample during defaults. Finally, the increase in bonds during default years is more pronounced in countries with more developed financial sector, as proxied by a high Private Credit/GDP ratio. 
Table 8

Banks' demand for government bonds.

\begin{tabular}{|c|c|c|c|}
\hline & $(1)$ & $(2)$ & (3) \\
\hline Sovereign Default $t_{t-1} *$ & $0.009^{* * *}$ & $0.011 * * *$ & $0.007^{* * *}$ \\
\hline Size $_{t-1}$ & $(0.003)$ & $(0.003)$ & $(0.003)$ \\
\hline Sovereign Default $t_{t-1}{ }^{*}$ & -0.013 & -0.042 & -0.041 \\
\hline Loans $_{t-1}$ & $(0.032)$ & $(0.037)$ & $(0.029)$ \\
\hline \multicolumn{2}{|l|}{ Sovereign Default $_{t-1} *$} & \multicolumn{2}{|l|}{$0.107^{* * *}$} \\
\hline \multicolumn{2}{|l|}{ Expected Sovereign Bond Return $n_{t-1}$} & \multicolumn{2}{|l|}{$(0.029)$} \\
\hline \multirow{2}{*}{$\begin{array}{l}\text { Sovereign Default }{ }_{t-1}^{*} \\
\text { GDP Growth } \\
\text { t-1 }\end{array}$} & 0.027 & \multicolumn{2}{|l|}{$1.758^{* * * *}$} \\
\hline & $(0.170)$ & \multicolumn{2}{|l|}{$(0.432)$} \\
\hline Sovereign Default $_{t-1} *$ & $0.035^{*}$ & \multicolumn{2}{|l|}{$0.172^{* * *}$} \\
\hline Banking Crisis $_{t-1}$ & $(0.021)$ & \multicolumn{2}{|l|}{$(0.045)$} \\
\hline Sovereign Default $_{t-1} *$ & $0.448^{*}$ & \multicolumn{2}{|l|}{$2.048^{* * *}$} \\
\hline \multicolumn{4}{|l|}{ Private Credit $_{t-1}$} \\
\hline \multirow[t]{2}{*}{ Sovereign Default ${ }_{t-1}$} & -0.123 & \multicolumn{2}{|l|}{$-1.501^{* * *}$} \\
\hline & $(0.158)$ & $(0.344)$ & $(0.055)$ \\
\hline \multirow{2}{*}{$\operatorname{Size}_{t-1}$} & $0.001^{* * *}$ & \multicolumn{2}{|l|}{0.001} \\
\hline & $(0.000)$ & $(0.000)$ & $(0.000)$ \\
\hline \multirow[t]{2}{*}{ Loans $_{t-1}$} & $-0.027^{* * *}$ & \multicolumn{2}{|l|}{$-0.047^{* * *}$} \\
\hline & $(0.004)$ & $(0.007)$ & $(0.004)$ \\
\hline \multicolumn{2}{|l|}{ Expected Sovereign Bond Return $n_{t-1}$} & \multirow{2}{*}{\multicolumn{2}{|c|}{$\begin{array}{l}-0.027^{* * *} \\
(0.008)\end{array}$}} \\
\hline & & & \\
\hline \multirow[t]{2}{*}{ GDP Growth $_{t-1}$} & $-0.164^{* *}$ & \multicolumn{2}{|l|}{-0.134} \\
\hline & $(0.066)$ & \multicolumn{2}{|l|}{$(0.096)$} \\
\hline \multirow[t]{2}{*}{ Banking Crisis $_{t-1}$} & $0.030^{* * *}$ & \multicolumn{2}{|l|}{0.022} \\
\hline & $(0.005)$ & \multicolumn{2}{|l|}{$(0.019)$} \\
\hline \multirow[t]{2}{*}{ Private Credit $_{t-1}$} & $-0.021^{* * *}$ & \multicolumn{2}{|l|}{$0.038^{* *}$} \\
\hline & $(0.004)$ & \multicolumn{2}{|l|}{$(0.018)$} \\
\hline Other controls? & Yes & Yes & Yes \\
\hline Year Dummies? & Yes & Yes & Yes \\
\hline Country Dummies? & & Yes & Yes \\
\hline Country x Year Dummies? & & & Yes \\
\hline No Observations & 13,082 & 5,341 & 26,549 \\
\hline No Banks & 2,896 & 2,103 & 5,124 \\
\hline No Countries & 38 & 29 & 157 \\
\hline R-squared & 0.801 & 0.739 & 0.814 \\
\hline
\end{tabular}

The table presents coefficient estimates from pooled OLS regressions. The dependent variable is bank bondholdings, and it is computed as bondholdings divided by total assets. Size is the natural logarithm of total assets; non-cash assets is total assets minus cash and due from banks, divided by total assets; leverage is one minus book value of equity (issued share capital plus other shareholders fund) divided by total assets; loans is total loans outstanding divided by total assets; profitability is operating income divided by total assets; exposure to central bank is total exposure to central bank divided by total assets; interbank balances is interest-earning balances with central and other banks divided by total assets; government owned is a dummy that equals one if the government owns more than $50 \%$ of the bank's equity. Sovereign default is a binary variable that equals 1 if the sovereign is in default in year t-1 and 0 otherwise; GDP growth is natural logarithm of GDP in year $t$ minus natural logarithm of GDP in year t-1; aggregate leverage is the country-year average of bank leverage; banking crisis is a binary variable that equals 1 if the country is in a banking crisis in year $\mathrm{t}-1$ and 0 otherwise; private credit is the ratio of credit from deposit taking financial institutions to the private sector to GDP, expressed as a percentage; exchange rate devaluation is the percent change in the exchange rate with the US dollar. Standard errors (in parentheses below the coefficient estimates) are adjusted for heteroscedasticity using the Huber (1967) and White (1980) correction, as well as for clustering at the bank level using the Huber (1967) correction. *** indicates significance at the $1 \%$ level; ** indicates significance at the $5 \%$ level; * indicates significance at the $10 \%$ level.

These estimates may be contaminated by country-level omitted factors, such as the supply of government bonds by the local government. ${ }^{22}$ In Column 2 we thus introduce country dummies. We also include expected returns, which is an interesting variable to consider even though it reduces our sample size. Our main findings on the demand for bonds during sovereign default are confirmed. The fact that banks with fewer outstanding loans do not increase their bondholdings during default years suggests that, at these times, public bonds do not end up being concentrated in "bad" banks, which further reinforces the supply hypothesis.

\footnotetext{
22 It could be, for instance, that governments in poorer and less financially-developed countries have higher debt levels for reasons that have nothing to do with the demand of bonds by banks. The inclusion of country dummies and country*time dummies allows us to mitigate these and other omitted variables concerns.
} 
Finally, Column 3 includes in our regression the interaction between country and time dummies to control for any country-specific shock. The main findings remain robust.

Overall, this section indicates that banks demand a sizeable amount of government bonds in normal times, particularly banks that have few investment opportunities and that operate in less financially developed countries. These results lend support to theories in which government bonds are held by banks in the regular course of their business activity, perhaps because they are good stores of value (e.g., Gennaioli et al., 2014) or because they can be used as collateral in repo agreements (e.g., Bolton and Jeanne, 2011).

In line with recent work on Europe, banks in our sample also appear to accumulate some bonds during sovereign defaults. In our data, though, this effect is quite small (about $3 \%$ of banks' assets on average) and it occurs mostly in large banks, which happen to be more profitable. Thus, our data do not support the notion that "bad" banks self-select themselves into buying bonds, as it seems to have been the case in the recent European crisis. ${ }^{23}$

The caveat here is that our data do not precisely measure holdings of domestic bonds. Hence, the increase in bondholdings during default years need not reflect greater domestic exposure. It is possible that, at such times, banks are actually purchasing foreign bonds. As we saw in Section 2.2, however, our data are quite informative about cross-bank variation in exposure to domestic government bonds. In this sense, although imperfect, our findings are likely to provide an accurate description of banks' heterogenous exposures to their government.

\section{Concluding remarks}

This paper uses a large bank-level sample containing 20 default episodes in 17 countries between 1998 and 2012 to document two robust facts. First, there is a strong negative correlation between a bank's holdings of government bonds and its lending during sovereign defaults. Second, bondholdings are large during normal times, particularly for banks that make fewer loans and are located in financially undeveloped countries.

Our findings are consistent with theories of imperfect creditor discrimination (e.g. Broner et al., 2010) and in particular with theories in which sovereign defaults damage domestic banks (Gennaioli et al., 2014). They indicate, moreover, that the sovereign default-banking crisis nexus is a feature of many countries around the world. Standard theories, in which the costs of default are only external, are thus bound to understate governments' incentives to repay their debts.

In addition, our results also point to important differences across countries according to their degree of economic development. The post-default decrease in bank lending appears to be stronger in countries with middle (as opposed to low) levels of economic and financial development, where financial intermediation plays an important role. There is little we can say about highly developed economies, since they simply do not default often enough in our sample.

Another important difference between emerging and advanced economies is that banks in emerging economies hold a large amount of bonds in normal times (12.7\% of assets in non-OECD countries). It is only natural to expect that these "normal-times" holdings should account for the bulk of the adverse effects of sovereign defaults on bank lending. In developed economies, by contrast, banks hold fewer bonds in normal times (5\% of assets in OECD countries) and their take-up of bonds during crises is more important in relative terms. This difference may have significant implications for bank regulation. When setting the risk-weights of government bonds, for instance, authorities should take into account that they can be an important part of banks' portfolios in normal times. More generally, regulatory efforts to curb banks' holdings of public bonds may impose sizeable costs without adding much in terms of improved incentives, particularly in countries where banks rely heavily on the liquidity services of public debt.

\section{Supplementary materials}

Supplementary material associated with this article can be found, in the online version, at doi:10.1016/j.jmoneco.2018. 04.011.

\section{References}

Amiti, M., Weinstein, D.E., 2011. Exports and financial shocks. Q. J. Econ. 126, 1841-1877.

Arteta, C., Hale, G., 2008. Sovereign debt crises and credit to the private sector. J. Int. Econ. 74, 53-69.

Acharya, V.V., Drechsler, I., Schnabl, P., 2014. A Pyrrhic victory? Bank bailouts and sovereign credit risk. J. Finance 69, $2689-2739$.

Acharya, V.V., Steffen, S., 2014. The greatest carry trade ever? Understanding Eurozone bank risks. NBER working paper 19039. J. Finan. Econ. Forthcoming. Baskaya, Y.S., Kalemli-Ozcan, S., 2014. Government Debt and Financial repression: Evidence from a Rare Disaster. University of Maryland working paper.

Battistini, N., Pagano, M., Simonelli, S., 2014. Systemic risk, Sovereign Yields and Bank Exposures in the Euro Crisis. Università di Napoli Federico II, Mimeo. Beck, T., Demirgüç-Kunt, A., Levine, R., 2000. A new database on financial development and structure. World Bank Econ. Rev. 14, 597-605.

Becker, B., Ivashina, V., 2014. Financial Repression in the European sovereign Debt Crisis. Harvard Business School working paper.

Bolton, P., Jeanne, O., 2011. Sovereign default risk and bank fragility in financially integrated economies. IMF Econ. Rev. 59 (2), $162-194$.

Borensztein, E., Panizza, U., 2008. The costs of sovereign default. IMF working paper.

Broner, F., Didier, T., Erce, A., Schmukler, S.L., 2013. Gross capital flows: Dynamics and crises. J. Monetary Econ. 60, 113-133.

Broner, F., Martin, A., Ventura, J., 2010. Sovereign risk and secondary markets. Am. Econ. Rev. 100, $1523-1555$.

Broner, F., Ventura, J., 2011. Globalization and risk sharing. Rev. Econ. Studies 78, 49-82.

Brutti, F., Sauré, P., 2013. Repatriation of Debt in the Euro crisis: Evidence for the Secondary Market Theory. Mimeo, University of Zurich.

\footnotetext{
23 See Acharya and Steffen (2014) and Brutti and Saure (2013) for evidence in this regard.
} 
Comelli, F., 2012. Emerging market sovereign bond spreads: Estimation and back-testing. Emerg. Markets Rev. 13 (4), $598-625$.

Cruces, J.J., Trebesch, C., 2013. Sovereign defaults: The price of haircuts. Am. Econ. J. 5, 85-117.

De Marco, F., 2017. Bank lending and the European sovereign debt crisis. J. Finan. Quant. Anal. forthcoming.

Djankov, S., McLiesh, C., Shleifer, A., 2007. Private credit in 129 countries. J. Financ. Econ. 84, 299-329.

Drechsler, I., Drechsel, T., Marques-Ibanez, D., Schnabl, P., 2014. Who borrows from the lender of last resort? J. Finance forthcoming.

Eaton, J., Gersovitz, M., 1981. Debt with potential repudiation: Theoretical and empirical analysis. Rev. Econ. Stud. 48, 284-309.

Gennaioli, N., Martin, A., Rossi, S., 2014. Sovereign default, domestic banks, and financial institutions. J. Finance 69, 819-866.

Huber, P.J., 1967. The behavior of maximum likelihood estimates under nonstandard conditions. In: Proceedings of the Fifth Berkeley Symposium on Mathematical Statistics and Probability, 1, pp. 221-233.

Iyer, R., Lopes, S., Peydró, J-L., Schoar, A., 2014. The interbank liquidity crunch and the firm credit crunch: Evidence from the 2007-09 Crisis. Rev. Financ. Studies 27 (1), 347-372.

Jimenez, G., Ongena, S., Peydró, J-L, Saurina, J., 2012. Credit supply and monetary policy: Identifying the bank balance-sheet channel with loan applications. Am. Econ. Rev. 102 (5), 2301-2326.

Karolyi, A., Stulz, R.M., 2003. Are financial assets priced locally or globally? In: Constantinides, G., Harris, M., Stulz, R.M. (Eds.) The Handbook of the Economics of Finance. Elsevier, Amsterdam, pp. 975-1020.

Kashyap, A., Stein, J.C., 2000. What do a million observations on banks have to say about the monetary transmission mechanism? Am. Econ. Rev. 90, 407-428.

Khwaja, A.I., Mian, A., 2008. Tracing the impact of bank liquidity shocks. Am. Econ. Rev. 98, 1413-1442.

Kim, G., 2010. EMBI Global and EMBI Global Diversified: Rules and Methodology. J.P. Morgan Securities Inc.

Kumhof, M., Tanner, E., 2008. Government debt: A key role in financial intermediation. In: Reinhart, C.M., Végh, C., Velasco, A. (Eds.), Money, Crises and Transition, Essays in Honor of Guillermo A. Calvo. MIT Press, Cambridge, MA, pp. 249-277.

Levy-Yeyati, E., Martinez Peria, M.S., Schmukler, S., 2010. Depositor behavior under macroeconomic risk: Evidence from bank runs in emerging economies. J. Money, Credit, Bank. 42, 585-614.

Paravisini, D., 2008. Local bank financial constraints and firm access to external finance. J. Finance 63 (5), $2161-2193$.

Paravisini, D., Rappoport, V., Schnabl, P., Wolfenzon, D., 2014. Dissecting the effect of credit supply on trade: Evidence from matched credit-export data. Rev. Econ. Stud. 82 (1), 333-359.

Pescatori, A., Sy, A.N.R., 2007. Are debt crises adequately defined? IMF Staff Papers 54 (2), 306-337.

Popov, A., Van Horen, N., 2014. Exporting sovereign stress: Evidence from syndicated bank lending during the euro area sovereign debt crisis. Rev. Finance 19 (5), 1825-1866.

Schnabl, P., 2012. The international transmission of bank liquidity shocks: Evidence from an emerging market. J. Finance 67 (3), $897-932$.

Shambaugh, J.C., 2004. The effect of fixed exchange rates on monetary policy. Q. J. Econ. 119, 301-352.

White, H., 1980. A heteroskedasticity-consistent covariance matrix estimator and a direct test for heteroskedasticity. Econometrica 817-838.

Zettelmeyer, J., Trebesch, C., Gulati, M., 2012. The Greek debt exchange: An autopsy. Econ. Policy 28, 513-569. 